\title{
TALK AND WRITE YOUR MATHEMATICAL THINKING
}

\author{
Gilang Kian Ishaya ${ }^{1}$, Rosalina Rolina ${ }^{2}$, Desy Tri Damayanti ${ }^{3}$ \\ ${ }_{1,2,3}$ IKIP Siliwangi, Cimahi \\ ${ }^{1}$ gilangkian@gmail.com, ${ }^{2}$ maezarou@gmail.com, ${ }^{3}$ desytridamayanti@yahoo.com
}

Received: Sep 15 ${ }^{\text {th }}, 2018 ;$ Accepted: Sep $18^{\text {th }}, 2018$

\begin{abstract}
The low mathematical communication ability (MCA) of junior high school students in Bandung Regency motivated this research. The aim of this study's to determine the comparison MCA of junior high school students in Bandung regency between the learning which using models Think Talk Write (Thitaw). This study used a quasi-experimental method with a pretest-posttest control group design involving two groups and randomly selected classes, at the beginning and end of the study the two classes were given a test. The population were junior high school students in Bandung Regency, while the sample consisted of two randomly selected classes. Obtained class VII A (experimental class) given the model Thitaw and class VII B (control class) is given a scientific approach. The instrument used was a 5-item MCA description test, then the MCA scores students'were analyzed with descriptive and inferential statistics using SPSS 21 software. Based on the results of the study, it was concluded that there were differences in the achievement of students' MCA using models Thitaw with students who used a scientific approach. And it had no interaction between learning by Think Talk Write with the initial mathematics ability.
\end{abstract}

Keywords: communication, model Think Talk Write

\begin{abstract}
Abstrak
Penelitian ini dilatarbelakangi oleh masih rendahnya kemampuan komunikasi matematik siswa SMP di Kabupaten Bandung. Penelitian ini bertujuan untuk memperoleh gambaran perbandingan kemampuan komunikasi matematik siswa SMP di Kabupaten Bandung antara yang pembelajarannya menggunakan model Think Talk Write (Thitaw). Metode yang digunakan dalam penelitian ini adalah metode kuasi eksperimen dengan disain kelompok kontrol pretes-postes yang melibatkan dua kelompok dan pengambilan sampel dilakukan secara acak kelas, pada awal dan akhir pembelajaran kedua kelas diberi tes. Populasi dalam penelitian ini adalah siswa SMP di kota Kabupaten Bandung, sedangkan sampelnya terdiri dari dua kelas yang dipilih secara acak. Diperoleh kelas VII A (kelas eksperimenI) yang diberi model Thitaw dan kelas VII B (kelas kontrol) diberi pendekatan saintifik. Instrumen yang digunakan adalah bentuk tes uraian kemampuan komunikasi matematik sebanyak 5 soal, kemudian data skor kemampuan komunikasi matematik siswa tersebut dianalisis dengan statistik deskriptif dan inferensial menggunakan bantuan software SPSS 21. Berdasarkan hasil penelitian, disimpulkan bahwa terdapat perbedaan pencapaian kemampuan komunikasi matematik siswa yang menggunakan model Thitaw dengan siswa yang menggunakan pendekatan saintifik. Dan tidak ada interaksi antara pembelajaran dengan Thitaw dengan kemampuan awal matematik.
\end{abstract}

Kata Kunci: komunikasi, model Think Talk Write

How to Cite: Ishaya, G.K., Rolina, R. \& Damayanti, D.T. (2018). Talk and Write Your Mathematical Thinking. JIML, 1 (3), 279-282.

\section{INTRODUCTION}

Mathematical learning requires active interaction between teachers and students, as well as between students. This is so that students can receive knowledge, master knowledge, have skills and skills as written in one of the goals of mathematics education according to Minister of National Education Regulation No. 22 of 2006 (Depdiknas, 2006) that communicates ideas with symbols, tables, 
diagrams, or other media to clarify the situation or problem. Similarly, Hermawan (2007) states, the function of mathematics learning is to develop the ability to communicate by using numbers and symbols that can help clarify and solve problems. This realizes that MCA are very important for students.

Mathematical communication ability (MCA) is a student's ability to convey something he knows through dialogue events that occur in the classroom environment so that the transfer of messages occurs, the message transferred contains about the mathematical material learned in class both written and oral. summarizing MCA is the process of expressing ideas and understanding of mathematics verbally, visually, and in writing, using numbers, symbols, graphic images, diagrams and words.

Sumarmo (Hendriana, H., Sumarmo, U., Rohaeti, 2014) summarizes that skills of MCA include the ability to express a situation into mathematical language, symbols, ideas, and mathematical models: explain and read meaningfully, express and understand, interpret and evaluate an idea of mathematics and mathematical presentation orally, writing or visually; listen, discuss and write about mathematics; and express an argument in his own language.

According to Surya (2004), learning has a meaning as a process carried out by individuals to obtain a new behavior change as a whole, as a result of the individual's own experience in interaction with his environment. Models Thitaw are can develop writing smoothly and train the language before writing it. The model Think Talk Write helps students to influence and manipulate ideas before writing them. The model Thitaw also helps students in gathering and developing ideas through structured conversations. According to Yamin, M., Antasari (2008), the design of a cooperative model t Thitaw by combining images and critical thinking. Students are required to be directly involved in critical thinking in organizing the contents of the essay systematically in the sequence of ideas ".

\section{METHOD}

The method of this research is quasi experimental method. This study involves two groups, the first's experimental group and the second's experimental group. All of them were given pretest and postes. The design patterns in this study as follows (Ruseffendi, 2005)

$\mathrm{O}$ X O

$\mathrm{O} \quad \mathrm{O}$

Information:

X: Learning using model think talk write

$\mathrm{O}$ : Pretes $=$ Postest (a question on pretest is the same as postes)

----: Random sampling of subjects

The population in this study were students in seventh of the junior high schools in Bandung Regency. The samples were taken randomly from the seventh grade students of junior high schools in the school. Then random sampling by class obtained class VII-A as an experimental class and class VII-B as a control class. Where the experimental class is given learning using models Thitaw and control classes get ordinary learning.

\section{RESULTS AND DISCUSSION}

\section{Results}

Table 1. Result of Two Path Anova

\begin{tabular}{lccccc}
\hline Source & $\begin{array}{c}\text { Type III Sum } \\
\text { of Squares }\end{array}$ & Df & $\begin{array}{c}\text { Mean } \\
\text { Square }\end{array}$ & F & Sig. \\
\hline Class & 102999 & 1 & 102999 & 9646, & 003 \\
\hline
\end{tabular}




\begin{tabular}{lrrrrr}
\hline level_kam & 39.807 & 2, & 19.903 & 1.864 & 0165 \\
class * ${ }^{*}$ level_kam & 19019 & 2 & 9510 & .891, & 416 \\
\hline
\end{tabular}

Based on Table 1 shows that the significance of learning methods and KAM is 0.416 . So the conclusion's no interaction between learning methods and KAM on the achievement of students' MCA. The significance value based on KAM is 0.165 . So it can be concluded that there is no interaction between learning methods and KAM on the achievement of students' MCA. Similarly, the achievement of MCA is not influenced by KAM. While the significance value based on the learning method is 0.003 . So it can be concluded that the learning method with ThiTaW model affects the achievement of students' MCA.

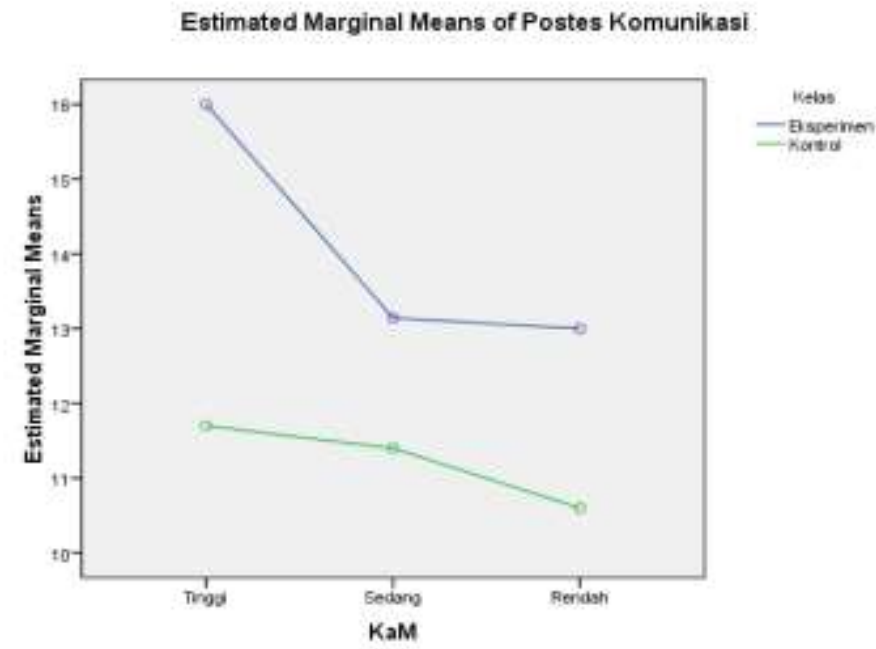

Figure 1. Graph Interaction KAM and Model Think Talk Write of Mathematical Communication Capabilities

In Figure 1 it appears that there is no interaction between learning methods and KAM in the high, medium and low groups.

\section{Discussion}

From the results of data processing it can be seen that learning with models Thitaw nfluences communication skills. To achieve MCA seen based on the learning method that learning using a model Thitaw in mathematics learning helps in the achievement of MCA. Whereas when viewed based on KAM that the difference is not significant between communication skills in certain KAM.

To increase MCA seen based on the learning method that learning using Thitaw models in mathematics learning helps in improving students' MCA. Whereas when viewed based on KAM that there is no significant difference between students' MCA in certain KAM.

Communication connects one thing to another. Models Thitaw encourage students to ask questions and then make mathematical models. The questioning process is the process of communicating. models Thitaw encourage students to develop writing smoothly and practice the language before writing it. This model flexible because it allows students to influence and manipulate ideas before writing them down. The model Thitaw encourages students to gather and develop ideas through structured conversations. As said Yamin, M., Antasari (2008) that the design of cooperative models Thitaw by combining images and critical thinking. The impact is not only developing communication skills, but also critical thinking skills. So cooperative learning Thitaw is learning in which students will begin by thinking (Think) how to find the solution of a problem, then the results of the thought will be discussed (Talk) with other students, so that the solution is then written (Write) the results thought and discussion. The activities of thinking, speaking and writing are a form of mathematics teaching and 
learning activities that gives opportunities for students to actively participate. Through these activities students can develop language skills appropriately, especially when conveying mathematical ideas.

\section{CONCLUSION}

Based on the results of the analysis and discussion as well as the findings obtained by the researchers, it can be concluded as follows:

1. Achievement of mathematical communication ability of junior high school students whose learning uses models Think Talk Write better than those using ordinary learning, reviewed as a whole and the initial abilities of their students .

2. There is no interaction between learning models Think Talk Write with students' initial abilities.

\section{REFERENCES}

Depdiknas. (2006). Permendiknas Nomor 22 Tahun 2006 Tentang Standar Isi. Jakarta: Depdiknas.

Hendriana, H., Sumarmo, U., Rohaeti, E. E. (2014). Kemampuan Komunikasi Matematik serta Kemampuan Disposisi Berfikir Kritis Matematik. Jurnal Matematika Dan Pendidikan Matmatika, 2(1).

Hermawan. (2007). Pengembangan Kurikulum dan Pembelajaran. Jakarta: Universitas Terbuka.

Ruseffendi, H. E. T. (2005). Dasar-Dasar Penelitian Pendidikan dan Bidang Non- Eksakta Lainnya. Bandung: Tarsito.

Surya, M. (2004). Learning and Teaching Psychology. Bandung: Library of the Children of Quraysh.

Yamin, M., Antasari, B. I. (2008). Ability Development Tactics Students Individual. Jakarta: Gaung Persada. 